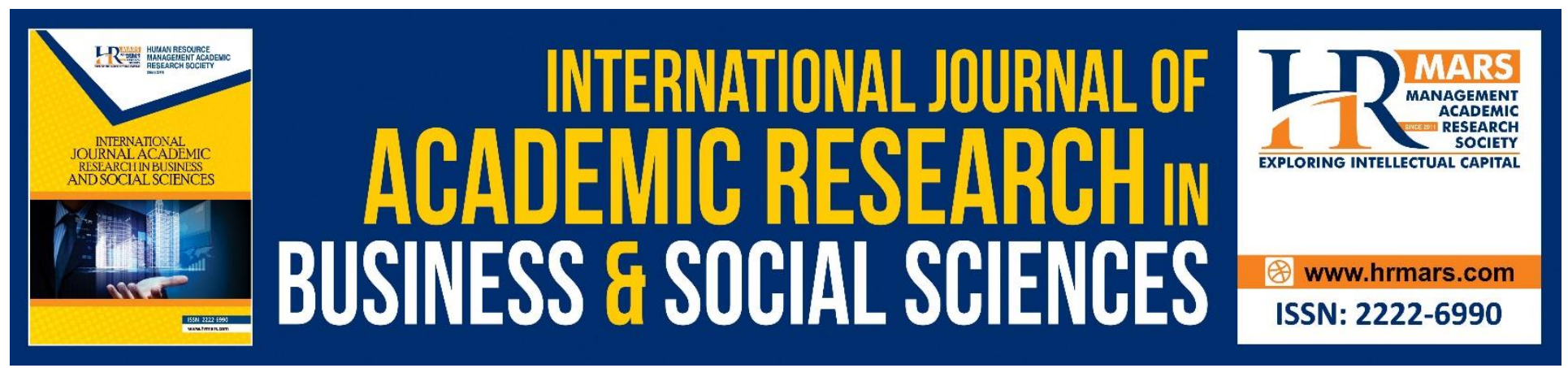

\title{
Role of Authentic Leadership, Servant Leadership and Destructive Leadership Behaviour on Employee Engagement in Malaysian Hospitality Industry
}

Gurpreet Kaur Parmar Ajaib Singh, Anusuiya Subramaniam, Anuar Shah Bali Mahomed, Rosmah Mohamed and Saadiatul Ibrahim

To Link this Article: http://dx.doi.org/10.6007/IJARBSS/v10-i9/7514

DOI:10.6007/IJARBSS/v10-i9/7514

Received: 06 June 2020, Revised: 14 July 2020, Accepted: 19 August 2020

Published Online: 14 September 2020

In-Text Citation: (Singh, Subramaniam, Mahomed, Mohamed, and Ibrahim, 2020)

To Cite this Article: Singh, G. K. P. A., Subramaniam, A., Mahomed, A. S. B., Mohamed, R., and Ibrahim, S. (2020). Role of Authentic Leadership, Servant Leadership and Destructive Leadership Behaviour on Employee Engagement in Malaysian Hospitality Industry. International Journal of Academic Research in Business and Social Sciences. 10(9), 113-125.

Copyright: (c) 2020 The Author(s)

Published by Human Resource Management Academic Research Society (www.hrmars.com)

This article is published under the Creative Commons Attribution (CC BY 4.0) license. Anyone may reproduce, distribute, translate and create derivative works of this article (for both commercial and non-commercial purposes), subject to full attribution to the original publication and authors. The full terms of this license may be seen at: http://creativecommons.org/licences/by/4.0/legalcode

Vol. 10, No. 9, 2020, Pg. 113 - 125

http://hrmars.com/index.php/pages/detail/IJARBSS

JOURNAL HOMEPAGE

Full Terms \& Conditions of access and use can be found at http://hrmars.com/index.php/pages/detail/publication-ethics 


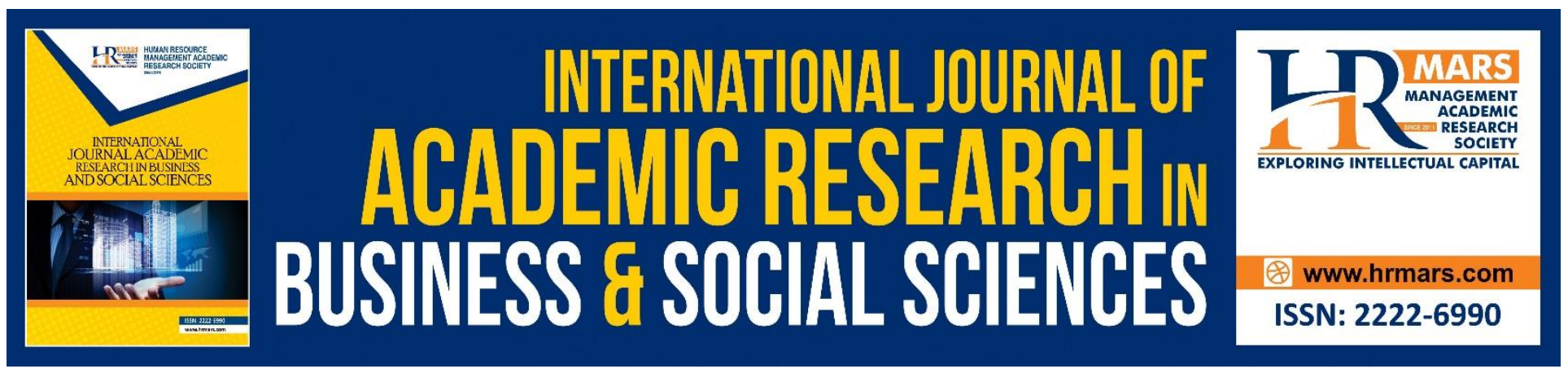

\title{
Role of Authentic Leadership, Servant Leadership and Destructive Leadership Behaviour on Employee Engagement in Malaysian Hospitality Industry
}

\author{
Gurpreet Kaur Parmar Ajaib Singh ${ }^{\mathrm{a}}$, Anusuiya Subramaniam ${ }^{\mathrm{b}^{*}}$, \\ Anuar Shah Bali Mahomedc, Rosmah Mohamed ${ }^{d}$ and Saadiatul \\ Ibrahime \\ ${ }^{a}$ Asia Pacific University of Technology \& Innovation (APU), Malaysia, b,c,d,eschool of Business and \\ Economics, Universiti Putra Malaysia, Malaysia.
}

Email : anusuiya@upm.edu.my

\begin{abstract}
To mobilize an engaged workplace, leadership becomes the key driver as effective superiors are able to shape employees' work attitudes and behaviours. In a monocultural context, authentic and servant leadership brings about positive organisational outcomes and vice versa for destructive leadership. Thus, it is valuable to evaluate the role of authentic, servant and destructive leadership behaviour on employee engagement among employees in hospitality industry, in a multi-cultural context such as Malaysia. This study executed a quantitative research design. A questionnaire survey among 100 employees attached to the Malaysian hotels in the Klang Valley area was carried out to test the hypotheses of this study. Data were analysed by utilising SPSS version 21.0 and PLS-SEM approach. The study retrieved the following: (1) authentic leadership has a significant and positive effect on employee engagement, (2) servant leadership has a significant and positive effect on employee engagement, (3) destructive leadership does not affect employee engagement. The top management of the hotels industry is encouraged to practice authentic leadership as well as servant leadership within their organisation since both of these leadership behaviours is being found to be effective in boosting up the level of employee engagement.
\end{abstract}

Keywords: Authentic Leadership, Servant Leadership, Destructive Leadership, Employee Engagement, Hotel

\section{Introduction}

Organisations have continually emphasized on the effective management of human capitals towards enhancing organisational performance. As posited by Grobelna (2019), fundamental distress for organisations is to keep hold of dedicated employees and facilitating their dedication towards organisational values. Employee engagement is being termed as a potential key towards tackling 
INTERNATIONAL JOURNAL OF ACADEMIC RESEARCH IN BUSINESS AND SOCIAL SCIENCES Vol. 10, No. 9, 2020, E-ISSN: 2222-6990 @ 2020 HRMARS

these difficulties and regularly studied among various scholars (Park et al., 2017). Employees who possess greater extent of engagement are essential for the organisational success (Yoo and Arnold, 2014). Prior studies have identified that organisations operate in an efficient manner due to engaged employees' capabilities to fulfil the role requirements effectively (Karatepe, 2014; Wahlberg, Ramalho and Brochado, 2017). Generally, management of service companies such as hotels endeavours to obtain and retain customer-contact employees who are worked-engaged (Min, Kim and Lee, 2015). Thus, it is essential to ensure that employees are highly engaged, committed and zestful towards offering outstanding customer service that meets the tourists' expectations as well as needs in order to attain service superiority (Suan and Nasurdin, 2016).

According to Hao and Yazdanifard (2015), to mobilize an engaged workplace, leadership becomes the key driver as effective superiors are able to shape employees work attitudes and behaviours. As supported by Gyensare, Arthur, Twumasi and Agyapong (2019), the extent of employee engagement depends on the leadership behaviour of the superiors. This indicates that leadership behaviours have significant influence on employees' engagement. For instance, authentic leaders were found to affect employees psychological state, behaviour and performance (Hu, $\mathrm{Wu}$, Zong, Xiao, Maguire, Qu et al., 2018). As posited by prior scholars, servant leadership approach assists in generating opportunities to enhance employees' growth in the organisation (Cai, Lysova, Khapova and Bossink, 2018; Kumar, 2018). According to Jacobs (2019), destructive leaders display continuing hostile behaviours, which contribute to employees' psychological distress and emotional exhaustion. However, associations between leadership behaviours and employee work engagement have only lately been theorized (Decuypere and Schaufeli, 2019). Very little, nevertheless is identified about the intensity, direction or the effect of such associations or what management researchers and practitioners possibly will do to be aware of the potential impact of authentic leadership, servant leadership and destructive leadership behaviour on an employee's engagement (Shuck, Owen, Manthos, Quirk and Rhoades, 2016).

According to $\mathrm{Ng}$ (2018), as a result of the history of Western colonization of Malaysia, the leadership approach among Malaysian companies is westernized. Nevertheless, Malaysian superiors are still are not anticipated to be egotistic, for instance, laying their own interest ahead of their subordinates as their way of conduct are still governed by their key cultural and religious values ( $\mathrm{Ng}$, 2018). Employees nowadays pursue immense authority and greater support from superiors; considering this occurrence will assist to increase employees' engagement in the workplace $(\mathrm{Ng}$, 2018). According to Awee, Cheah, Cheng, Hong, Ling and Tan (2014), there is necessity to improve and strengthen all Malaysian sectors including hospitality and services industry performance and reputation. Thus, it is very important for superiors to understand leadership quality to administer entire organization in an effective and efficient manner. It is well known that in a monocultural context, authentic and servant leadership brings about positive organisational outcomes and vice versa for destructive leadership. However, regardless of the theoretical support pertaining to the association between leadership behaviour (authentic, servant and destructive leadership) on employee engagement, there are still limited empirical studies with regards to the hospitality industry (Qiu and Dooley, 2019).

The personification of human resource development research, theory and practice is to generate and uphold organizational efficiency through employee contributions and human resource systems in the workplace (Kataria, Garg and Rastogi, 2013). Various studies on human resource development have discovered authentic, servant leadership and destructive leadership behaviour 
INTERNATIONAL JOURNAL OF ACADEMIC RESEARCH IN BUSINESS AND SOCIAL SCIENCES Vol. 10, No. 9, 2020, E-ISSN: 2222-6990 @ 2020 HRMARS

and employee engagement distinctly or the combined effect of two of the constructs together (Peter, 2016). Nevertheless, lack of empirical study has examined the combined effect of these four essential constructs together; authentic leadership, servant leadership, destructive leadership behaviour and employee engagement. Thus, it is valuable to evaluate the role of authentic leadership, servant leadership and destructive leadership behaviour on employee engagement among employees in hospitality industry, in a multi-cultural context such as Malaysia. Therefore, this study contributes empirical evidence on these constructs and also to the literature and purpose of human resource development research and practice.

\section{Theoretical Background and Hypotheses Development}

The theory of employee engagement established the root of the conceptual framework for this study. Precisely, employee engagement theory developed by Kahn (1990) was used to grasp the strategies that superiors utilize to engage their employees. Engaged employees exhibit commitment, bestow their greatest efforts, are innovative and focus on quality, costs, customer service and safety (Kahn, 1990). However, disengagement happens when employees withdraw physically, cognitively and emotionally from their responsibilities at workplace (Kahn, 1990). Employee engagement is essential towards attaining strategic goals by generating the conditions, resources and working atmosphere for leadership to be successful and for employees to be productive (Anitha, 2014). Scholars utilize the theory of employee engagement to focus the strategies superiors can utilize towards engaging their employees and for employees to enhance employees' productivity and effectiveness (Albrecht, Bakker, Gruman, Macey and Saks, 2015). Thus, the theory of employee engagement is pertinent as it aligns with this study, as leadership behaviour can affect employee engagement (Popli and Rizvi, 2016).

Amid the numerous important workplace consequences in the management literature, employee engagement has drawn robust attention (Shuck et al., 2016). Employee engagement is termed as a dynamic, job-associated optimistic psychosomatic condition, operationalized by the strength and path of cognitive, emotional and behavioural energy (Shuck et al., 2016). The determinants of employee engagement depend on the leaders on how they lead their followers in the organisation (Anitha, 2014). In the context of employee engagement, the front-runners represent a noteworthy role thus they become the organisation's best leader (Popli and Rizvi, 2016). For the survival of an organisation, the relationship between a supervisor and supervisee is very essential. This is because this rapport will have an influence on the outcome of behavioural and the engagement process (Chaurasia and Shukla, 2013). For that reason, it is crucial to delve into revelation on the possible effect of authentic leadership, servant leadership and destructive leadership on employees' engagement.

According to the Bill George's Authentic Leadership Model, those individual who has a sense of purpose is known as an authentic leader as they are aware of what they are expecting from their followers (Powlus, 2017). Thus, authentic leadership will result in the optimistic outcome of an organisation (Azanzaa, Morianob and Molerob, 2013). For instance, employees who are under the guidance of an authentic leader will tend to have a higher gratification of job and highly committed to their organisation (Wong and Laschinger, 2013). As revealed by prior scholars, sharing information impartially, transparently and amenable with the employees is another culture of an authentic leader (Men and Stacks, 2014). The characterises that is held by an authentic leader such as having communication in two ways, transparency, higher disclosure level with the employees creates an 
INTERNATIONAL JOURNAL OF ACADEMIC RESEARCH IN BUSINESS AND SOCIAL SCIENCES Vol. 10, No. 9, 2020, E-ISSN: 2222-6990 @ 2020 HRMARS

optimistic atmosphere in the organisation and subsequently enhances employee engagement (Men, 2015). Therefore, it is hypothesised that:

H1: When the supervisors portray authentic leadership behaviour, the employee engagement tends to boost up portentously.

According to Burkus (2010), the fresh leadership theory which disputes that most effective leaders are the servants of the employees, which is termed as servant leadership. Through the wholehearted attention to the employees as well as the needs of the employees, the servant front-runner gets the desired outcome for their organisation (Burkus, 2010). In order for a leader to be a leader that leads their followers, they must first be the servant to others. A servant leader has the capability to instigate the employees: initially by assisting them and then by guiding the employees (Chen, Chen and Li, 2013). Prior scholars argued that servant leadership stimulates employees' spiritual development, wellbeing and work-related outcomes, such that they become highly engaged, open-minded, patient and attentive in their job (Chen et al., 2013). This indicate that servant leadership behaviour stimulate robust conduit in enhancing employee engagement. Therefore, it is hypothesised that:

H2: When the employees are led by the servant leaders, employee engagement will be enhanced.

According to Aasland, Skogstad, Notelaers, Nielsen and Einarsen (2010), encouraging the supervisees to work in contradiction of the organisational goals as well as portraying behaviour that is unlawful in the workplace is known as destructive leadership. Generally, the destructive leader will tend to harass, bully and betray their employees and also deny the elementary humanity of their employees. If the employees have done any mistake, they are not given the chance to explain the exact situation but rather they will be punished by their destructive leaders. This will absolutely will have an impact on the employees' overall performance. This is because the employees who are treated in such a bad way by their destructive leader will be undergoing stress thus they will be unable to focus on the organisation. Likewise, by creating immoral strategic verdicts such as through practicing negative judgment, this destructive leader can ravage their employees (Yen, Tian and Sankoh, 2013). Therefore, when the employees have been treated in such a way, they are more likely to be less engaged in the workplace (Grobelna, 2019). Therefore, it is hypothesised that:

H3: Under destructive leaders, employees will be less engaged in the workplace.

\section{Methodology}

\section{Participants and Procedure}

The study was conducted in Malaysia, an emerging country located in South-East Asia. Participants were employees attached to the seven hotels in the Klang Valley area. In this study, purpose sampling was utilized. A number of hotels in the Klang Valley area were contacted and the hotels that corresponded to take part were selected. Entirely, employees from seven hotels were respondents in this study. The questionnaires were disseminated with the assistance of Human Resource Administrator of the respective hotels that decided to be part of this research. The Human Resource Administrator assisted to get the questionnaires filled up by the hotel employees. Participants were provided envelopes to return the questionnaire sealed to confirm on confidentiality. The 
INTERNATIONAL JOURNAL OF ACADEMIC RESEARCH IN BUSINESS AND SOCIAL SCIENCES Vol. 10, No. 9, 2020, E-ISSN: 2222-6990 @ 2020 HRMARS

accomplished questionnaires were then dispatched by utilising the given self-addressed stamped envelopes. A total 150 self-administered questionnaires were distributed and 100 usable questionnaires were returned.

\section{Measurement}

Towards obtaining the data for this research, a questionnaire was designed. All the statements in the questionnaire were rated on a 5-point Likert scale ranging from 1(strongly disagree) to 5(strongly agree). Authentic Leadership was measured using 10-item authentic leadership inventory (ALI) by Neider and Schriesheim (2011). Sample scale item include "My immediate supervisor let others know who truly he/she as a person". Servant leadership was measured using 10-item scale by Liden, Wayne, Zhao and Henderson (2008). The sample scale items include "My immediate supervisor holds high ethical standards". Destructive leadership was measured using 10 -item scale by Einarsen, Skogstad, Aasland and Løseth (2002). Sample scale items include "My immediate supervisor has humiliated me if we do not live up to his/her standards". 10-item shortened version of Utrecht work engagement scale by Schaufeli, Salanova, González-Romá and Bakker (2002) was used to assess employee engagement. The sample items for each dimension are: "When I get up in the morning, I feel like going to work".

\section{Profile of Respondents}

Out of 100 respondents who have answered the questionnaires that have been distributed to them, the results indicated that $57 \%$ of them were male and $43 \%$ of them were female. With regards to their age, $25 \%$ of respondents were aged under 25 years old, $22 \%$ of respondents were aged between 26 to 30 years old, $15 \%$ of respondents were aged between 31 to 35 years old, $21 \%$ of respondents were aged between 36 to 40 years old and $17 \%$ of respondents were aged 41 years old and above. In terms of race, $34 \%$ of respondents were Malay, $30 \%$ of respondents were Chinese, $27 \%$ of respondents were Indians and the remaining $9 \%$ of respondents were from Others category. With regards to marital status, $35 \%$ of respondents were single and $65 \%$ of respondents were married. In terms of educational level. $21 \%$ of respondents had obtained high school certification, $24 \%$ of respondents are Diploma holders, 24\% of respondents are Bachelor's Degree holders, $18 \%$ of respondents are Master's Degree holders and 13\% of the respondents are Ph.D. holders. With regards to duration of working experience, $15 \%$ of respondents exhibited less than 1 year working experience, $16 \%$ of respondents exhibited between 1 to 3 years working experience, 18\% of respondents exhibited between 3 to 5 years working experience and $51 \%$ of respondents exhibited more than 5 years working experience. In terms of respondents' position level, $59 \%$ of the respondents were middle-level employees and $41 \%$ of the respondents were lower level employees.

\section{Analytical method}

Data were analysed by utilising SPSS version 21.0, to generate frequencies and percentages to present the main characteristics of the sample and SmartPLS version 3 with the Structural Equation Modelling (SEM) approach, generated the standardized value of the path coefficients. SmartPLS was adequate for this study because it simplified the issue of sample size (Chin and Newsted, 1999). By using SmartPLS software, the study was able to compute the measurement scales and investigate the structural model (Hair, Sarstedt, Ringle and Gudergan, 2018). 
INTERNATIONAL JOURNAL OF ACADEMIC RESEARCH IN BUSINESS AND SOCIAL SCIENCES Vol. 10, No. 9, 2020, E-ISSN: 2222-6990 @ 2020 HRMARS

\section{Common method variance}

Harman's one factor test was conducted towards assessing the extent of common method variance (Podsakoff and Organ, 1986). All the scale items were incorporated into an unrotated factor analysis towards detecting whether a single factor accounted for the majority of covariance among the constructs. This process results in a seven factor (Eigenvalues greater than 1.0) solution, where the first factor accounted for $44.29 \%$ of the variance, which is less than $50 \%$. This reveals that the common method bias does not emerge to be a severe problem in the study.

\section{Results}

Reliability and validity of measurement

Table 1 exhibits the descriptive statistics, average variance extracted (AVE) and correlations among the study constructs. Support for reliability and validity of the measurement models was obtained, with the composite reliability (evidence of internal consistency reliability) beyond 0.70 (Nunnally \& Bernstein, 1994), AVE (for instance evidence of convergent validity) above 0.50 (Hair, Hult, Ringle and Sarstedt, 2014) and the square root of the AVE values more than the relationship between the construct and each of the other constructs (discriminant validity) (Fornell and Larcker, 1981). The additional inspection of the cross loadings revealed that all scale items had their utmost coefficients with their associated construct, delivering additional evidence for discriminant validity (Hair et al., 2014). Additionally, each predictor variable's VIF value was greater than 0.20 and lower than 5, demonstrating that collinearity was not a dispute here (Hair et al., 2014).

\section{Table 1}

Descriptive statistics, average variance extracted (AVE), composite reliability (CR) and correlation coefficients.

\begin{tabular}{llcccccccc}
\hline No & Construct & Mean & SD & AVE & CR & $\mathbf{1}$ & $\mathbf{2}$ & $\mathbf{3}$ & $\mathbf{4}$ \\
\hline 1. & $\begin{array}{l}\text { Authentic } \\
\text { leadership }\end{array}$ & 4.39 & 0.79 & 0.80 & 0.97 & $\mathbf{( 0 . 9 )}$ & & & \\
2. $\begin{array}{l}\text { Servant } \\
\text { leadership }\end{array}$ & 4.43 & 0.83 & 0.79 & 0.98 & $0.9^{* *}$ & $\mathbf{( 0 . 9 )}$ & & \\
3. $\begin{array}{l}\text { Destructive } \\
\text { leadership }\end{array}$ & 4.26 & 0.38 & 0.56 & 0.86 & 0.17 & 0.16 & $\mathbf{( 0 . 7 5 )}$ & \\
4. $\begin{array}{l}\text { Employee } \\
\text { engagement }\end{array}$ & 4.39 & 0.79 & 0.76 & 0.97 & $0.9^{* *}$ & $0.9^{* *}$ & 0.5 & $\mathbf{( 0 . 8 7 )}$ \\
\hline
\end{tabular}

Notes: $n=100$; Bold-faced numerals on the diagonal represent the square root of the average variance extracted.

All correlations are two-tailed; ** significant at $p<0.01$;

\section{Hypothesis Testing}

Findings of this study are summarized in Figure 1. PLS-SEM generated the standardized value of the path coefficients, the significance of which was measured by comparing the empirical t-value with the critical value, with the former derived from the original path coefficient estimate divided by the bootstrap standard error (Hair et al., 2014). In this research, bias-corrected bootstrapping confidence intervals were obtained based on 5000 bootstrap samples using the no-sign-changes approach. The first hypothesis, which predicted a positive relationship between authentic leadership behaviour and 
INTERNATIONAL JOURNAL OF ACADEMIC RESEARCH IN BUSINESS AND SOCIAL SCIENCES Vol. 10, No. 9, 2020, E-ISSN: 2222-6990 @ 2020 HRMARS

employee engagement was supported. The result showed a significant positive path coefficient $(b=0.48, t=5.87, p=0.00)$. Hypothesis 2 , which predicted a positive relationship between servant leadership behaviour and employee engagement was also supported $(b=0.49, t=5.61, p=0.00)$. However, Hypothesis 3 , which hypothesized that a negative relationship between despotic leadership and employee engagement was not supported $(b=0.04, t=1.03, p=0.30)$.

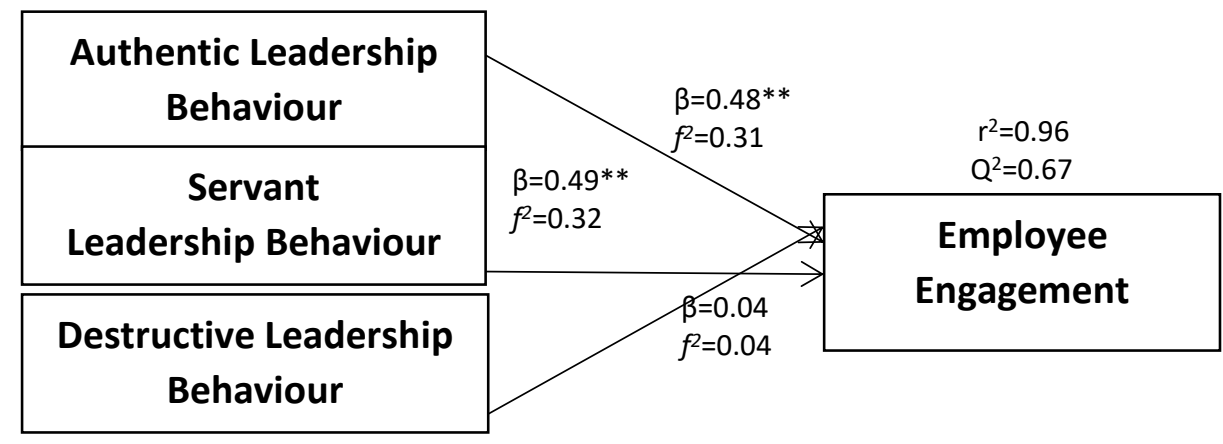

Figure 1. Research model: results of the structural model assessment.

\section{Model Performance Assessment}

The estimated model seems to have a good predictive power assessing by the calculated $\mathrm{R}^{2}$ values of 0.96 for employee engagement. The Stone-Geisser's $Q^{2}$ value for endogenous construct (Geisser, 1974) was computed by utilizing the blindfolding procedure for an omission distance of 9 . $A Q^{2}$ value greater than zero reveals that the predictive relevance of the model for the related endogenous constructs, however a value of zero or less indicates a lack of predictive relevance (Hair et al., 2014). The Stone-Geisser's $Q^{2}$ analysis yielded $Q^{2}$ value of 0.67 for employee engagement which are noticeably beyond the threshold value of zero.

\section{Discussion}

The results of this study are consistent with prior researches that indicate authentic leadership influence employee engagement (Penger and Černe, 2014). This might due to the optimistic nature of authentic leadership aligning with the positive attributes that supervisors and organization make an effort to generate, such as greater levels of employee engagement. It is likely that the nature of the hospitality sector being association oriented could precisely build authentic leadership style an exemplar for this atmosphere. That is, this kind of leadership might innately have a great deal to do with generating a good employee and customer affiliated atmosphere, which describes the exactness of authentic leadership in hospitality settings.

As predicted, the results of the current study indicated servant leadership as a significant predictor of employee engagement. This result is in accordance with the results obtained by prior scholars examining this arena (Abid, Gulzar and Hussain, 2015). As being identified by prior researchers, as a means of benefiting individually within the organisations, these servant leaders encourage the power-sharing between two parties which is the employees and frontrunners (Abid et al., 2015). Furthermore, enriching the caring working environment and overall quality of organisational life as well as seeking their followers to participate fully in the process of decision making is one of the attitudes that stands out in these servant leaders. Additionally, the hotel 
INTERNATIONAL JOURNAL OF ACADEMIC RESEARCH IN BUSINESS AND SOCIAL SCIENCES Vol. 10, No. 9, 2020, E-ISSN: 2222-6990 @ 2020 HRMARS

employees can freely proceed towards their goals when they are under the supervision of servant leaders.

Contrary to expectation, the findings of this study identified that destructive leadership is not associated with employee engagement, in which it is coherent with prior research (Platek, 2015). As identified by Platek (2015), supervisors who display destructive leadership behaviour do not lead to a decrease in employees' engagement. Employees were identified to be extensively receptive towards negative aspects of external context, which can cultivate a greater impact on attitudes and conducts compared to positive contextual aspects. Supervisors of hotel employees are likely to retaliate or emulate their supervisees with mistreatment to enhance supervisees' engagement. Thus, hotel administrators should conduct training programmes for hotel employees to get rid of problems that arise and towards enhancing their morale in facing negative consequences in the workplace. Furthermore, a grievance or ombudsman system for hotel employees is required towards preventing supervisors from being destructive towards their employees.

This study provides insights into mechanisms through which servant and authentic leadership influence employee engagement among hotel employees. Servant leadership has a greater impact effect on employee engagement than authentic leadership in hospitality enterprises. Servant leaders put forth more direct and effective values in the hospitality industry, providing empirical evidence for the argument that hospitality industries need servant leadership (Ling, Lin and Wu, 2016). As supervisor behaviours can generate and strengthen through formal organization policies, hospitality organizations can encourage servant leaders through a series of HR policies and practices, including selection, training, evaluation and rewards (Ling et al., 2016). Precisely, hospitality firms ought to consider choosing or promoting new managers with characteristics of optimism, integrity, solid ethics and service orientation (Brownell, 2010). Training programs are essential to assist supervisors acknowledge the value and principles of servant leaders (for instance, work ethics and self-sacrifice) and to assist them improve skills like empathy and empowerment (Liden et al., 2008). Performance evaluations and reward systems for hotel managers must take into account the main characteristics and competences of servant leaders (for instance, performing ethically and assisting employees towards their progress develop). Simultaneously, these practices foster managers to incorporate servant/authentic leadership principles into regular work. Thus, hospitality firms could carry out authentic leadership as a foundation to cultivate servant leadership and cultivate servant leadership to exert a higher effect on employees (for instance, alter employees to grow healthier, wiser, freer, more autonomous and selfless), which would inspire employees to treat customers more actively and selflessly.

As Malaysia is a multicultural country, the results of this study may become a reference for other Southeast Asia countries which consist of only one ethnic group as the mainstream population. This study conveys resolutions for the employee engagement issues of the hotel industry in Malaysia by demonstrating the prominence of servant and authentic leadership. The findings encourage that potent strategies can be established and training programs can be upgraded to ease the employee engagement issues.

\section{Conclusions, Limitations and Direction For Future Research}

Leadership is an essential subject matter in the human resource development, management and organisation behaviour territories due to the distinctive and obligatory function leadership portrays in shaping the overall success and direction of organizations (Roncesvalles and Sevilla, 2015). With 
regards to the theoretical standpoint and theory building, this study has contributed toward the understanding on the leadership behaviour that can influence employee engagement among hotel employees in the Malaysian context. Precisely, the results of this study pointed to a number of implications for human resource development practice: the need to design and implement programs that develop authentic and servant leadership behaviour in current and future superiors; the need for superiors and employees to understand the importance of engagement.

In summary, the human capital of a hotel is the "employees". The hotel employees are regarded as the valuable assets to the hotels. The success and failure of a hotel lies on the employees. Only hotel employees who are highly engaged will endeavor to work hard in the hotel. Specifically, the top management of the hotels is encouraged to practice authentic leadership as well as servant leadership among the hotel employees since both of these leadership behaviours are effective in boosting up the level of employee engagement among employees in the hotel industry, compared to destructive leadership behaviour. This is because it is fundamental for every hotel to have highly engaged hotel employees in order for the hotels to achieve their competitiveness.

This study has few drawbacks that exist. In view of the shortcomings of the cross-sectional design, forthcoming studies should take into account longitudinal data to determine causal associations and to identify developmental changes over time among these constructs. As only predictor of employee engagement is being identified in this study, future research could be expanded to study the outcomes employee engagement and the mutual effects among its predictors and outcomes. Finally, a further study could be associated on both employee engagement and disengagement by expanding the scope of study. These are something to be studied in future research.

\section{Declaration of Conflicting Interests}

The authors declare that they have no conflicting interests.

\section{Funding}

This research received no specific grant from any funding agency in the public, commercial or notfor-profit sectors.

\section{References}

Aasland, M. S., Skogstad, A., Notelaers, G., Nielsen, M. B., Einarsen, S. (2010). The prevalence of destructive leadership behavior. British Journal of Management, 21(2), 438-452.

Abid, H. R., Gulzar, A., Hussain, W. (2015). The impact of servant leadership on organizational citizenship behaviors with the mediating role of trust and moderating role of group cohesiveness; A Study of public Sector of Pakistan. International Journal of Academic Research in Business and Social Sciences, 5(3), 234-242.

Albrecht, S. L., Bakker, A. B., Gruman, J. A., Macey, W. H., Saks, A. M. (2015). Employee engagement, human resource management practices and competitive advantage: An integrated approach. Journal of Organizational Effectiveness: People and Performance, 2, 7-35.

Anitha, J. (2014). Determinants of employee engagement and their impact on employee performance. International Journal of Productivity and Performance Management, 63(3), 308-323.

Azanzaa, G., Morianob, J., Molerob, F. (2013). Authentic leadership and 
INTERNATIONAL JOURNAL OF ACADEMIC RESEARCH IN BUSINESS AND SOCIAL SCIENCES

Vol. 10, No. 9, 2020, E-ISSN: $2222-6990$ ๑ 2020 HRMARS

organizational culture as drivers of employees' job satisfaction. Journal of Work and Organizational Psychology, 29(2), 45-50.

Brownell, J. (2010). Leadership in the service of hospitality. Cornell Hospitality Quarterly, 51(3), 363-378.

Burkus, D. (2010). Servant leadership theory. Retrieved 20 January 2020, from http://davidburkus.com/2010/04/servant-leadership-theory

Cai, W. J., Lysova, E. I., Khapova, S. N., Bossink, B. A. G. (2018). Servant leadership and innovative work behavior in Chinese high-tech firms: a moderated mediation mode of meaningful work and job autonomy. Frontiers in Psychology, 9, 1-13.

Chaurasia, S., Shukla, A. (2013). The Influence of Leader-Member

Exchange Relations on Employee Engagement and Work Role Performance. International Journal of Organization Theory and Behavior, 16(4), 465-493.

Chen, C.-Y., Chen, C.-H., Li, C.-I. (2013). The influence of leader's spiritual values of servant leadership on employee motivational autonomy and eudaemonic well-being, Journal of Religion and Health, 52(2), 418-438.

Chin, W. W., Newsted, P. R. (1999). Structural equation modeling analysis

with small samples using partial least squares. In R.H. Hoyle (Ed.), Statistical strategies for small sample research. (pp. 307-341). Sage Publications: Thousand Oaks.

Decuypere, A., Schaufeli, W. (2019). Leadership and work

engagement: Exploring explanatory mechanisms. German Journal of Human Resource Management, 1-27.

Einarsen, S., Skogstad, A., Aasland, M. S., Løseth, A. M. S. B. (2002). Destructive leadership: preductirs and consequences. In A. Skogstad and S. Einarsen (Eds.), Leadership for Better or Worse. Effienciency and Job Satisfaction (pp. 233-254). Bergen: Fagbokforlaget.

Fornell, C., Larcker, D. F. (1981). Evaluating structural equation models with unobservable variables and measurement error, Journal of Marketing Research, 18(1), 39-50.

Geisser, S. (1974). A predictive approach to the random effects model. Biometrika, 61(1), 101-107.

Grobelna, A. (2019). Effects of individual and job characteristics on hotel contact employees' work engagement and their performance outcomes. International Journal of Contemporary Hospitality Management, 31(1), pp. 349369.

Gyensare, M., Arthur, R., Twumasi, E., Agyapong, Joan-Ark (2019). Leader effectiveness - the missing link in the relationship between employee voice and engagement. Cogent Business \& Management, 6(3), 1-20.

Park, G. J., Kim, S. J., Yoon, S., Joo, B. (2017). The effects of empowering leadership on psychological well-being and job engagement. Leadership \& Organization Development Journal, 38(3), 350-367.

Hair, J. F., Hult, G. T. M., Ringle, C. M., Sarstedt, M. (2014). A Primer on Partial Least Squares Structural Equation Modeling (PLS-SEM). CA: Thousand Oaks.

Hair, J. F., Sarstedt, M., Ringle, C. M., Gudergan, S. P. (2018). Advanced issues in partial least squares structural equation modeling (PLS-SEM). Sage Publications: Thousand Oaks.

Hao, M. J., Yazdanifard, R. (2015). How effective leadership can facilitate 
INTERNATIONAL JOURNAL OF ACADEMIC RESEARCH IN BUSINESS AND SOCIAL SCIENCES

Vol. 10, No. 9, 2020, E-ISSN: 2222-6990 @ 2020 HRMARS

change in organizations through improvement and innovation. Global Journal of Management and Business Research, 15(9), 1-6.

Jacobs, C. M. (2019). Ineffective-Leader-Induced Occupational Stress. SAGE Open, Retrieved 15 January 2020, from https://doi.org/10.1177/2158244019855858

Kahn, W. A. (1990). Psychological conditions of personal engagement and disengagement at work. Academy of Management Journal, 33, 692-725.

Karatepe, O. M., Beirami, E., Bouzari, M., Safavi, H. P. (2014). Does work engagement mediate the effects of challenge stressors on job outcomes? Evidence from the hotel industry. International Journal of Hospitality Management, 36, 14-22.

Kataria, A., Garg, P., Rastogi, R. (2013). Employee engagement and organizational effectiveness: The role of organizational citizenship behavior. International Journal of Business Insights \& Transformation, 6(1), 102.

Kumar, S. (2018). Servant Leadership: A Review of Literature. Pacific Business Review International, 11(1), 43-50.

Liden, R. C., Wayne, S. J., Zhao, H., Henderson, D. (2008). Servant leadership: Development of a multidimensional measure and multi-level assessment. Leadership Quarterly, 19(2), 161-177.

Ling, Q., Lin, M., Wu, X. (2016). The trickle-down effect of servant leadership on frontline employee service behaviors and performance: A multilevel study of Chinese hotels. Tourism Management, 52(1), 341-368.

Men, L. R. (2015). Employee Engagement in Relation to Employee-

Organization Relationships and Internal Reputation: Effects of Leadership Communication. Public Relations Journal, 9(2), 1-22.

Men, L., Stacks, D. (2014). The Effects of Authentic Leadership on Strategic Internal Communication and Employee-Organization Relationships. Journal of Public Relations Research, 26(4), 301-324.

Min, H., Kim, H. J., Lee, S. B. (2015). Extending the challenge-hindrance stressor framework: The role of psychological capital. International Journal of Hospitality Management, 50, 105-114.

Neider, L. L., Schriesheim, C. A. (2011). The authentic leadership inventory (ALI): Development and empirical tests. The Leadership Quarterly, 22(6), 11461164.

Ng, X. Le. (2018). The Relationship Between Perceived Servant Leadership Characteristics, Human Resource Practices and Turnover Intention in Small Medium Enterprises. Retrieved 1 January 2020, from https://www.google.com/url?sa=t\&rct=j\&q=\&esrc=s\&source=web\&cd=1\&cad=rja\&uact=8\& ved=2ahUKEwjJ95Kz2ZXIAhWLt|8KHXxYApoQFjAAegQIAxAC\&url=http\%3A\%2F\%2Feprints.ut m.my\%2Fid\%2Feprint\%2F79586\%2F1\%2FNgXinLePFM2018.pdf\&usg=AOvVaw2orDKbLm08ceg9j6HpMkV

Nunnally, J. C., Bernstein, I. H. (1994). Psychometric theory. Columbus, OH: McGraw Hill.

Penger, S., Černe, M. (2014). Authentic leadership, employees' job satisfaction, and work engagement: a hierarchical linear modelling approach. Economic Research-Ekonomska Istraživanja, 27(1), 508-526.

Peter, A. B. (2016). The Impact of Authentic Leadership Behavior on 
INTERNATIONAL JOURNAL OF ACADEMIC RESEARCH IN BUSINESS AND SOCIAL SCIENCES

Vol. 10, No. 9, 2020, E-ISSN: 2222-6990 @ 2020 HRMARS

Employee Engagement and Organizational Ethical Culture in Nigeria. Retrieved 1 July 2020, from http://hdl.handle.net/

$10950 / 511$

Platek, T. A. (2015). Destruktiv lederatferd i det norske Forsvaret: en kvantitativ studie om sammenhengen mellom destruktiv lederatferd og utbrenthet, jobbengasjement og organisasjonsforpliktelse.(Master), Forsvaret høgskole, Oslo.

Podsakoff, P., Organ D. (1986). Self-reports in organizational research: problems and Prospects. Journal of Management, 12, 531-543.

Popli, S., Rizvi, I. A. (2016). Drivers of employee engagement: The role of leadership style. Global Business Review, 17(4), 965-979.

Powlus, A. (2017). Five Characteristics of Authentic Leadership. Retrieved 15 January 2020, from https://doi.org/10.1177/2158244019855858

Qiu, S., Dooley, L. (2019). Servant leadership: Development and validation of a multidimensional measure in the Chinese hospitality industry. Leadership \& Organization Development Journal, 40(2), 193-212.

Roncesvalles, M. C. T., Sevilla, A. V. (2015). The Impact of Authentic Leadership on Subordinates' Trust and Work Performance in Educational Organization: A Structural Equation Modeling. Journal of Educational and Management Studies, 5(1), 69-79.

Schaufeli, W. B., Salanova, M., González-Romá, V., Bakker, A. B. (2002). The measurement of engagement and burnout: A two sample confirmatory factor analytic approach. Journal of Happiness Studies, 3(1), 71-92.

Shuck, B., Owen, J., Manthos, M., Quirk, K., Rhoades, G. (2016). Coworkers with benefits: benefits: The influence of commitment uncertainty and status on employee engagement in romantic workplace relationships. Journal of Management Development, 35(3), 382-393.

Suan, C., Nasurdin, A. (2016). Supervisor support and work engagement of hotel employees in Malaysia: Is it different for men and women? Gender in Management: An International Journal, 31(1), 2-18.

Wahlberg, T., Ramalho, N., Brochado, A. (2017). Quality of working life and engagement in hostels. Tourism Review, 72(4), 411-428.

Wong, C., Laschinger, H. (2013). Authentic leadership, performance and job satisfaction: the mediating role of empowerment. Journal of Advance Nursing, 69(4), 947959.

Yen, T., Tian, Y., Sankoh, F. (2013). The Impact of Prevalent Destructive Leadership Behaviour on Subordinate Employees in a Firm. American Journal of Industrial and Business Management, 3(7), 595-600.

Yoo, J. J., Arnold, T. J. (2014). Customer orientation, engagement, and developing positive emotional labour. The Service Industries Journal, 34(16), 1272-1288. 